Cahiers $d u$ MONDE RUSSE

\section{Cahiers du monde russe}

Russie - Empire russe - Union soviétique et États indépendants

40/1-2 | 1999

Archives et nouvelles sources de l'histoire soviétique, une réévaluation

\title{
Ports of access into the mental and social worlds of Don villagers in the 1920s and 1930s
}

\section{D'Ann R. Penner}

\section{(2) OpenEdition}

1 Journals

\section{Electronic version}

URL: http://journals.openedition.org/monderusse/9

DOI: 10.4000/monderusse. 9

ISSN: $1777-5388$

\section{Publisher}

Éditions de l'EHESS

\section{Printed version}

Date of publication: 1 January 1999

Number of pages: 171-198

ISBN: 2-7132-1314-2

ISSN: $1252-6576$

Electronic reference

D'Ann R. Penner, « Ports of access into the mental and social worlds of Don villagers in the 1920s and 1930s », Cahiers du monde russe [Online], 40/1-2 | 1999, Online since 15 January 2007, Connection on 20 April 2019. URL : http://journals.openedition.org/monderusse/9 ; DOI : 10.4000/monderusse.9 


\section{PORTS OF ACCESS INTO THE MENTAL AND SOCIAL WORLDS OF DON VILLAGERS IN THE 1920s AND 1930s*}

IN LATE MARCH OF 1994, I boarded the 6:15 Novoshakhtinsk-bound electric train, armed with a letter of introduction, a list of fondy, and the published address of the Shakhty Filial of the Rostov State Archive (ShFGARO), 33 Stalin Prospekt. Rostovian historians, living 45 kilometers away, had never considered it necessary to do research in Shakhty and had looked a bit bemused at my inquiries. "There is no Stalin Prospekt in Shakhty," a taxi driver at the train station pronounced. One information desk, a street car, a bus, and three helpful strangers later, I stood before the archive's entrance, which was barred by a broom handle keeping the two doors closed from the inside. After five minutes of buzzing, a middle-aged woman peered out the window and asked me to state my business, after which I was taken immediately to see the director, Rimma Ivanovna, a 68-year-old woman clad in three layers of clothing chosen for warmth, not style. An inexpensive, worn fur hat adorned her cropped, white hair. Her bushy, black eyebrows and lack of urbane social graces clearly bespoke her peasant origins. Rimma Ivanovna abruptly dismissed the obliging archivist and turned to dispense with the disheveled American who must surely have lost her senses or her way. My topic, shortened by fear from "farmer-Party relations in the Don Region" to "Cossacks and collectivization," was declared irrelevant in an era of disintegrating collective farms. Moreover, Shakhty was and remains, as any fool would know, she said, the center of coal-mining country in the Don area; I would find no sources on either Cossacks or

\footnotetext{
* I dedicate this article to Rimma Ivanovna. My thanks extend to all those who have contributed, intentionally or otherwise, to my research efforts: Kathy Brady, Thomas Brady, Jr., Jeffrey Burds, Vladlen Izmozik, Nina Ivanovna, Liudmila Evdokimovna, Nicholas Riasanovsky, Yuri Slezkine, Lynne Viola and Reginald Zelnik. The funding for various phases of this research was provided by the George Z. and Ludmilla Patrick Foundation, the American Council of Teachers of Russian, the International Research and Exchanges Board, the Social Science Research Council, the Kennan Institute for Advanced Russian Studies, and the University of Memphis.
} 
collectivization. After a short "discussion," Rimma Ivanovna, hoping that I would be more quickly despatched by a few hours spent perusing opisi, ushered me into a damp, poorly lit "reading room," and instructed her staff to bring me all the opisi and dela I requested without delay. The descriptions in the opisi were curt: dated protokoly for every state organization from the district (okrug) to the township (sel'sovet) level with an occasional topic-of-the-day thrown in for spice. A thick layer of dust lined the previously undisturbed pages of the sample dela I ordered.

The Shakhty archive was the second-to-last stop on a two-year tour of central and provincial archives I had identified as relevant to my dissertation, a study of villager-Party interaction in the plains of the lower Don river basin from 1920 until 1933. As an ethnographic historian, I had been trying, in the words of Richard Price, "to penetrate the existential worlds" of my subjects - Party officials, mainly local, as well as Cossack and peasant farmers - and "to evoke their texture."1 I had already gathered more than enough material for two books after working nine months in three central archives (GARF, RGAE, RTsKhIDNI) - by Russian and American reckoning alike, the archives with the most "important" holdings, fourteen months at the state and Party repositories for the Northern Caucasus Territory (Severo-Kavkazskii krai) from 1924 through 1934, housed in Rostov-onDon; and two weeks in the Krasnodar provincial archives (TsDNIKK and GAKK) in order to track down additional information on three border counties which had shifted from Kuban to Don jurisdiction and back again between 1925 and $1930 .^{2}$

After being approached by the third inebriated stranger while waiting at the Rostov train station for a bus home at 10:30 p.m., the question did cross my mind - in light of the seven hours required on public transportation each day, the unenthusiastic and defiant response of the archive's director, and the dark, damp, chilly, and dusty (by Russian standards) working conditions, could there possibly be sources in Shakhty justifying my effort? If archival directors at opening interviews were to be believed, however, I would have had to conclude a long time ago that there were no materials on Cossacks in the Rostov archives, no materials on northern Kuban, one-time Don counties in Krasnodar. Rimma Ivanovna herself beckoned as a story wrapped in an enigma - what kind of a woman in her thirteenth year of "retirement" would continue to protect Party secrets in 1994 while demanding maximal productivity from herself and her crew on a budget too scant to allow for replacement glass for the broken window in her own office?

At first glance it would seem that the historian of popular mentalities during the first decades of Soviet power must be awash in a sea of unusually choice documents,

1. R. Price, Alabi's world (Baltimore, 1990): xix.

2. I use the term "Don region" to refer to what in 1920 was known as the Don oblast' (province) - the Upper Don, First Don, Cherkassk, Rostov and Sal'sk okrugi and the Taganrog and Shakhty okrugi (temporarily part of Ukraine), all of which became part of the North Caucasus from 1924 until 1934, when the names and boundaries were once again readjusted and the above-named areas became part of the Azov-Chernomorskii krai; Spravochnik: territorial'nye preobrazovaniia $i$ pereimenovaniia naselennykh punktov Rostovskoi oblasti za 1937-1970 gg. (Rostov, 1976). 
directly created or at least inspired by the narod. After all, both the words and the resistive actions of villagers were preserved in historical depositories by the Bolshevik government, which created forums, both oral and written, for villagers to voice their opinions, complaints, and suggestions. It also frequently undertook policies that aroused villagers' fury and commissioned agents of the secret police, procuracy, and Worker-Peasant Inspectorate to overhear, observe, and interview villagers, and then to report their findings in writing to more central authorities.

At second glance, however, almost all of the letters and transcribed oral expressions were written or spoken to Soviet or Party institutions or representatives, agents of what historians working in the 1990s, aware of the variety of penalties for expressing opinions contrary to the reigning political wisdom, have had trouble conceptualizing as anything other than "Power" in the most pejorative sense of the word. ${ }^{3}$ By definition, if we follow James Scott, most of these sources are part of what he refers to as the "public transcript," or the "open interactions between subordinates and those who dominate," and hence of questionable value.

There are numerically insignificant exceptions to this general rule - letters exchanged between Cossack relatives living in Prague and Novo-Minsk, or between a son serving in the Red Army and his wife or father back home. ${ }^{4}$ Yet once again, thanks to the secret police's practice of intercepting and reading such letters, ${ }^{5}$ it is not clear that all or even most of the letter-writers felt themselves to be communicating "beyond direct observation by power holders," Scott's criterion of the "hidden transcript."6 From my reading of Cossack letters published in émigré journals during the 1920s and 1930s, I would estimate that, even in the mid-1920s, at least one in four of these letter writers was suspicious of mail tampering, as can be seen by their habit of speaking in parables and by direct reference to written letters never received. Before 1930, however, letters written by soldiers to their parents or vice versa show few signs of suspicion or concern. By contrast, in 1930, soldiers, to appease their commanding officers, were routinely writing letters to join collective farms, while sending a second letter - just in case it got through - urging their parents to disregard the first one.?

Used in isolation, there is no perfect source invulnerable to abstract criticism for the historian interested in popular mentalities. Almost all of the above-named

3. For repression on the Don after March 1921, see D'Ann R. Penner, Pride, power, and pitchforks: Farmer-Party interaction on the Don, 1920-1928 (hereafter Pride) (Ph.D. diss., University of California at Berkeley, 1995), (1921-1924): 126-135, 203-206, and (1928): 559565 .

4. Letters from Don Cossacks to their relatives abroad are available in many émigré journals, including Kazachii put', and Kazach'i dumy; excerpts from soldiers' letters are available at TsDNIRO, f. 7 (Severnyi Kavkazskii kraevoi komitet - SKKK), op. 1, d. 195 and 202, and RGVA, f. 9 (Politicheskoe Upravlenie Raboche-Krest'ianskoi Krasnoi Armii - PU RKKA).

5. See Vladlen Izmozik, "Voices from the twenties: Private correspondence intercepted by the OGPU,” trans. by W. K. Wolf, Russian Review, 55 (April 1996): 287-308.

6. All above references to Scott are taken from Domination and the arts of resistance: Hidden transcripts (New Haven - London, 1990): xii-xiii, 2-4. In this case, it seems to me, the perception of privacy is more important than the reality.

7. Svodka PU RKKA, March 1930, RGVA, f. 9, op. 28, d. 161,1.3. 
sources (and many more), used critically and in combination, however, can serve a useful, though not equal, role in the reconstruction of plausible, multi-dimensional popular mental worlds. The most generous, frank, and least problematic veins of popular sources, I will argue, are amongst the documents generated in the townships (sel'sovety) or counties (raiony), wherever they may be housed today. ${ }^{8}$ Thanks to the unique quality of its sources and the working conditions afforded by an efficient, conscientious, and (ultimately) hospitable director, the "Shakhty Filial" turned out to be not superfluous but critical to my endeavor. ${ }^{9}$

\section{OGPU svodki}

Since the opening of the archives in 1991, the OGPU svodki have easily been among the most popular "new" genre, available sporadically at least, to foreign historians. ${ }^{10}$ The "absolutely confidential" nature of the materials and the efforts made by loyal Party directors and high-ranking Russian patriots to limit access to police materials even today can incline easily impressionable historians to lose their criticality once access to svodki has been gained. Nonetheless, several concerns must be addressed. The least useful part of the OGPU svodki is the analysis by agents untrained in and unconcerned about scholarly methods, clearly working under ideological pressures and time constraints. Obviously, OGPU analysis provides no substitute (or even advisable starting point) for late twentiethcentury analysis, which can rest on sources, perspectives, and methods unavailable to the OGPU analysts. The evaluation of OGPU svodki is complicated by an unknown informer's motivations and uncertain reliability as a stenographer, the personal or political agenda of the OGPU compiler, and the pressures from higherranking officials under whom the compiler was forced to work. ${ }^{11}$ Reports by OGPU agents who actually spent time in the villages, county seats, and market towns give significantly more space to an actual transcription of remembered popular dialogue, either overheard, proffered or elicited in conversation. ${ }^{12}$ The percentage of "analysis" to quoted villagers' voices in OGPU svodki, for example, decreases

8. All of which is not to disparage the importance of Moscow holdings, which in my project have provided useful supplements to my provincial diggings, and which warranted, in part because of the former Lenin Library, almost one third of my time. In the Party archival system, county materials are preserved in the County Committee (raionnyi komitet - RK) fondy, which I have found to be exceptionally useful. In the Rostov Party Archive, my strategy was to read all the opisi for every level from RK to Territorial Committee (kraevoi komitet - KK) for each year of my study for every county except one, an Armenian-dominated county near Rostov.

9. By "Shakhty Filial," I include the Taganrog Filial as well as RK files located at TsDNIRO.

10. For an overview of secret police reports, see the introduction to A. Berelowitch, V.P. Danilov, eds, Sovetskaia derevnia glazami VChK-OGPU-NKVD, 1918-1933 gg. Dokumenty $i$ materialy, 1: 1918-1922 (Moscow: Rosspen, 1998): 7-53.

11. Terry Martin raised some of these issues in his AAASS paper, "The OGPU and the politics of information," in Boston, 1996.

12. The same is true of reports by traveling prosecutors, Rabkrin inspectors, and District Executive Committee (okruzhnoi ispolkom - OIK) instructors. 
sharply the further one gets away from Moscow-generated reports. The countylevel compilations also have the advantage of having been through the fewest editorial selection processes, processes which inevitably reflect the biases and pressures under which the editor labored.

The descriptions of conversations and incidents are inevitably more complete at the county level, where even crowd responses to "inflammatory" speeches are included, as is, often, the fate of the speaker. On August 8, 1926, a group of farmers, reportedly poorer than average, gathered on a street corner near the Co-op in the center of a Taganrog-district market town. In the middle of their discussion of high prices and the economic health of the country as a whole, Shevchenko, a peasant farmer on leave from Khar'kov, where he was attending courses at the Institute of Defenders of the People, intervened. He drew, in the opinion of the OGPU reporter, "a perfectly correct picture of the situation." His speech, however, was interrupted by Machenko, a native of the village, who now worked as a foreman at a metallurgy factory in Taganrog. "How [he asked his former villagers] can you stand to listen to such outright lies? [...] I work at a factory and I'll tell you exactly how things are. The majority of workers receive between 35 and 60 rubles a month and these workers are having a very tough go of it [...] Every day no fewer than ten workers come up to me and ask for help. I do what I can, but of course it isn't enough. Where, I ask you, is justice to be found?" The crowd, which by this time had doubled in size, was so distressed that it did not allow Shevchenko to say another word. In the opinion of the reporting OGPU agent, both the Soviet government and the Party lost a considerable measure of respect in the eyes of Taganrog farmers on that day for failing to alleviate the sufferings of workers. ${ }^{13}$

County-originated OGPU incidents, preferably compiled by a county, district or territorial agent, hold unparalleled potential for both vertical and horizontal comparison. In both the Shakhty and Taganrog Filials (ShFGARO and TFGARO), 600-page files focus on the respective districts for 1925-1926, allowing for a comparison of attitudes and responses by region during the least restricted years of NEP. ${ }^{14}$ Vertically by year, comparable files exist for the Sal'sk district in 1927 and Remontnensk county in 1933, to give only two of the most valuable examples. ${ }^{15}$

Provincial archives, particularly the more remote ones, can offer ways of sidestepping the accessibility obstacles one sometimes confronts in Moscow. ${ }^{16}$ Frequently, OGPU reports are interspersed among the protokoly of Party Bureau meetings from the County to the Territorial Committee, in which case they are

13. OGPU IS (informatsionnaia svodka), 28 Aug. 1926, TFGARO, f. R-10 (Taganrog OIK), op. 1, d. 307,1.437.

14. TFGARO, f. R-10, op. 1, d. 307 and ShFGARO, f. R-278 (Shakhtinsko-Donetsk OIK), op. 2, d. 40 .

15. TsDNIRO, f. 97 (Sal'sk District Committee (okruzhnoi komitet - OK)), op. 1, d. 76, and TsDNIRO, f. 94, op. 1, d. 202.

16. It is, of course, possible that the central FSB archive contains runs of county-originated svodki from every county in the Union for every year. For now, however, access is limited to very narrow requests from extremely well-connected individuals. 
almost never identified in the opisi, a saving grace in the years after 1993 when OGPU svodki again became taboo. ${ }^{17}$ In some cases, entire runs of OGPU svodki have been fortuitously mislabeled by an archivist as "circular letters" or "protokoly." In other cases, OGPU observations of village activities are preserved in city Soviet (gorsovet) fondy (Shakhty, 1933) or Trade Union (profsoiuz) files. ${ }^{18}$ This "availability," however, varies sharply from archive to archive. In the former Krasnodar Party archive, every file was examined page by page before it was given to me. If the screener found a single page written by an OGPU reporter or a Control Commission (kontrol'naia komissiia) panel, access to the entire delo was denied.

The OGPU summary report of "noteworthy" conversations and activities arguably comes the closest to giving us a glimpse at the "hidden transcript," notoriously difficult to access. A representative or paid intermediary of "Power" is obviously present. Nonetheless, after having read tens of thousands of OGPU entries written between 1920 and 1933, and drawn from every district of the former Don province, I find it clear that, especially in the 1920s, either secret police agents were extraordinarily creative at inventing a remarkable range of dialogues and characters week after week, or most of the overheard villagers (including Cossacks) were unaware of the informer in their midst and felt free to criticize Soviet power and to articulate their complaints.

The potential uses of these "voices," if uninvented, are almost limitless, but two stand out. It is one thing to hear in a Moscow-originated OGPU report that, in the compiler's words, "kulak resistance to grain requisitioning in the Northern Caucasus Territory remains unbroken" in January of 1933. The OGPU reporter working in Veshensk county, by contrast, takes us directly into the heart of the resistance by quoting the words of collective farm workers in a black-listed village who were refusing to ratify a new procurements order: "We are dying from starvation and our children are eating frozen squash. Even if you exile us, even if you shoot us - there still won't be any grain."19

These tens of thousands of reported conversations and outbursts at meetings generate distinctive personalities and meaningful groupings - even within seemingly homogeneous groups like Cossacks or inogorodnie (so-called outsiders) - by attitude toward the Soviet government, personality type, preferred tactics, and values. They defy Soviet classification devices which followed a "class"based hierarchy (bedniaki, seredniaki, and zazhitochnye) or tended to divide Cossacks up in a binary fashion: friends and foes. ${ }^{20}$ My classifications are based primarily (but not exclusively) on the ample dialogues and scenarios of the OGPU

17. GAKK, f. R-692 (Eisk County Executive Committee (raionnyi ispolkom - RIK)), op. 1, d. $9,1.53$.

18. GARO, f. R-2287 (SKK sovet professional'nykh soiuzov), op. 3s, dd. 104, 106, 119; ShFGARO, f. R-186 (Shakhtinskii gorodskoi ispolkom), op. 1 d. 421.

19. OGPU IS, 29 Jan. 1933, GARO, f. R-2287, op. 3s, d. 119, 1. 45.

20. For a summary of Soviet historians' treatment of Don Cossacks, see D'Ann Penner, "Vzaimootnosheniia mezhdu donskimi i kubanskimi kazakami i Kommunisticheskoi partiei, 1920-1932," Golos minuvshego (Nov. 1996): 23-26, here 23. 
reports. The obligatory introductory and concluding sentences - the overwhelming majority of bedniaki are on our side, the seredniaki are wavering but will end up on our side, and the kulaki are (and will remain) against us - can be ignored.

Among Cossacks, the range, I have argued, runs from those who are proudly and adamantly hostile to the Bolshevik project to those who fought in the Red Army during the Civil War and remained loyal to the Communist Party through at least 1928. Hostile Cossacks shared a common attitude toward the Soviet government, best expressed, I believe, by Aleksei Egorov, a Cossack from the Sal'sk district, in June 1927: "The Soviet government is as repulsive as soured vomit. It is run by people we wouldn't even have hired to slop hogs earlier." 21 During the Party-farmer stand-off of 1928, otherwise known as the "grain crisis" of 1928, one defiant Cossack, who was deliberately not turning his surplus grain over to the Soviet agents, was overheard asserting: "I would rather burn my grain than give it to the Bolsheviks."22 Similarly, rumors of war were greeted by hostile Cossacks with undisguised enthusiasm: "No matter which [foreign] government declares war against us, life can only get better," one of them reasoned. ${ }^{23}$ "It would be better to suffer the agonies of war," old-timer Cossacks in the Kuban asserted, "than to continue living under Soviet rule." 24 In the middle of the spectrum were conquered Cossacks - that is, those who were farmers first, warriors second. They preferred peace at any cost. Young Cossack soldiers stationed in Eisk even offered to pay more taxes, if the Soviet government should encounter difficulties in buying off the would-be attackers. ${ }^{25}$ At the other end of the Cossack spectrum stood a group of diehard loyalists. A group of Sal'sk partisans was still able in 1928 to recite from memory the speech Budennyi, the great Red Cossack general, made beckoning them to join with him in the fight. The majority of Red partisans of the Sal'sk district, some of whom were Cossack, not only declared their "readiness at any minute to stand in defense of the Soviet government," but were upset that the Soviet government was not allowing the recruitment of volunteers to fight in China on the side of the Chinese workers and peasants. ${ }^{26}$ While most of the loyalist Cossack farmers shared some of

21. OGPU IS, Kormovoe (Dubovsk county), TsDNIRO, f. 97, op. 1, d. 76, 1. 82.

22. OGPU IS, 20 Jan. 1928, TsDNIRO, f. 7, op. 1, d. 801, 1. 35ob. OGPU reports and Party correspondences from this period are full of similar statements by other Cossacks; see Progress report from the North Caucasus Territorial Control Commission (SKKKK) to the Central Control Commission (TsKK), Veshensk, 11 Feb. 1928, GARF, f. 374 (Narodnyi komissariat raboche-krest'ianskoi inspektsii - NK RKI), op. 28, d. 2543, 1. 114; Village correspondent's letter to Sovetskii pakhar', Novo-Stepanovka (13 March 1928), TsDNIRO, f. 7, op. 1, d. 769, 1. 90; Report to the OGPU by the Chairman of TsKK, Starannikov, following his trip to the Kuban, 20 June 1928, GARF, f. 374, op. 27,d. 1490,1.41.

23. OGPU IS, 15 and 21 June 1927, TsDNIRO, f. 7, op. 1, d. 595, 11. 52, 91.

24. OGPU IS, 15 June 1927, quoted, 1.93.

25. Don OK plenum (OKP) drawn from OGPU reports, 1927, TsDNIRO, f. 5 (Don OK), op. 1, d. $99,1.35$ b. The soldiers at the Eisk camp were drawn from the Staro-Minsk, Kushchevsk and Eisk counties. For reports of similar sentiments by Cossacks, see Inspector's report, 1927, TsDNIRO, f. 5, op. 1, d. 160, 1. 114ob; Don OK biuro (OKB) 20 Oct. 1927, TsDNIRO, f. 5, op. 1,d. 128,1.9.

26. OGPU IS, Sal'sk district, 1927, TsDNIRO, f. 79, op. 1, d. 79,1. 1. 
the complaints of their less pro-Bolshevik neighbors, there was never any question of where they would stand should war be declared on the Soviet Union. In May of 1927, at the height of a much-publicized and seriously taken war scare, a group of former Red partisans and demobilized soldiers stood discussing politics. According to the OGPU agent present, they all agreed: "Though we rag on the Soviet government, we will defend it come what may." ("Khot' my rugaem Sovetskoi vlasti, vse ravno my budem ee zashchishchat'." $)^{27}$

It is difficult to imagine a non-Cossack OGPU agent creating a script wherein Cossacks are offering to pay more taxes. Throughout the 1920s, as the OGPU agent had been faithfully reporting, week after week, the Cossacks had complained of onerously high taxes which, they believed, Cossacks should be exempt from paying because their forefathers had never paid taxes. ${ }^{28}$ Is it likely that an OGPU agent who, however dependable from a Party point of view, is not known for his colorful imagery and sharp wit but who is rather fond of the Communist Party for saving him from his father's fate of "slopping hogs" for arrogant Cossacks, would be able to come up with the graphic, emphatic, deeply rooted-in-disgust metaphor which likens the Soviet government to "soured vomit"?

The accuracy of the political police, who made a series of preemptory arrests in June 1928, was cursed by Cossacks in Tselina, a hamlet in the Sal'sk district, if the reporting OGPU agent is to be believed. "Those sons of bitches [...] made their selections without a single mistake. It's as if the arrested had the word 'guilty' written across their foreheads." ${ }^{29}$ Particularly in this instance, it is tempting to view the OGPU reporter's efforts as self-congratulatory and possibly fabricated. On the other hand, OGPU "accuracy" in removing potential Cossack uprising leaders probably helps to explain why Cossack resistance to collectivization and dekulakization in 1930 ultimately was not more organized, united, and successful. Present-day authentication as to the viability of the entire range of above-quoted voices representing defiant, conquered and loyal Cossacks was enthusiastically given in September 1996 by both Kuban atamany and a Don Cossack historian, born and raised in Veshensk, who considered them fully in character with the kinds of words and sentiments expressed by their older relatives. ${ }^{30}$

\section{Conference interventions}

A second source genre which improves in quality the farther one gets from Moscow is the conference intervention, by which I mean the short, impromptu commentary,

27. OGPU IS, 1 May 1927, TsDNIRO, f. 7, op. 1, d. 595,1. 92.

28. OGPU report, 1927, TsDNIRO, f. 5, op. 1, d. 141,1. 14; OGPU IS, 12 Nov. 1923, RGAE, f. 478 (Narkomzem RSFSR), op. 15, d. 10,1.62; TsDNIRO, f. 7, op. 1,d. 195,1.37; and Pride, ch. 8.

29. OGPU IS, Sal'sk district, 28 June 1928, TsDNIRO, f. 97, op. 1, d. 76, 1.111.

30. Discussion and private comments following my paper, "Litsom k kazachestvu," presented at the Kuban Cossack 300-year anniversary conference in Poltavskaia stanitsa, Krasnodar, Sept. 1996. 
rebuttal, or query after the orations of state or Party representatives. ${ }^{31}$ It offers a potentially invaluable port of entry into the minds and thought processes of people who, on the whole, when they were able to write, did so laboriously. Among villagers, the overwhelmingly preferred (that is, natural and comparatively effortless) medium of communication was oral. A bright, charismatic, yet unschooled villager, male or female, can be a gifted public speaker, as many of the OGPU svodki bear out. ${ }^{32}$ Taken as a whole, this genre is most vulnerable to the criticism of being a forum where attendees were under obvious moral, if not always physical, pressure to adjust their comments according to their perceptions of what the Communist Party organizers attending wanted to hear.

Before the genre can be dismissed wholesale, two assumptions must be evaluated. The first assumption - that consequences for "speaking truth to Power" were consistently negative during the 1920 s - is mistaken. There were certainly years when many peasants and Cossacks believed that "to make an open criticism [of a local Party figure or Soviet power generally] is to invite immediate seizure," as farmers from the village of Varlamov (Shakhtinsko-Donets district) confided to the visiting district representative in June, 1925.33 Gorlanov, secretary of one Taganrog County Committee, drawing attention to the dramatic way in which the peasants of his county had changed their views on the village cell and their participation habits in the meetings, admitted: "In an earlier period, it was not uncommon for villagers at the close of a cell meeting to inquire, 'Well, who are you arresting this time?'" 34 Condemned to the position of minority rule and lacking the means of commanding genuine respect, a substantial portion of the rural Communists entrusted with the tasks of keeping order and collecting taxes from 1922 to 1924 ruled with an iron fist. Ill-equipped with education or natural wit, these men found it more effective to avoid embarrassing questions put to them by their more articulate opponents by arresting the "smart mouth." 35

The Party's much-publicized Face-to-the-Countryside (Litsom $k$ derevne) campaign, though subject to abrupt and often unannounced changes, brought

31. Sheila Fitzpatrick was one of the first scholars to point out the benefit of conference stenograms, especially to social historians, often as not because they contain statements which were considered asides by the convening Party organizers. She also observed that not all Partyconvened conferences were of equal value. "Sources on the social history of the 1930s: Overview and critique" in Sheila Fitzpatrick, Lynne Viola, eds, A researcher's guide to sources on Soviet history in the 1930s (New York: M.E. Sharpe, 1990): 3-25, here 10-14.

32. Geroid T. Robinson reached a similar conclusion in Rural Russia under the Old Regime, paper-bound edition (Berkeley — Los Angeles, 1967).

33. Letter to Shakhtinsko-Donets OIK from Konstantinovsk RIK, June 1925, ShFGARO, f. R278 , op. 2 , d. $45,1.59$.

34. Informatsionnyi obzor (IO), Taganrog district, Nov. 1925, TsDNIRO, f. 104 (Taganrog OK), op. 1, d. 174, 1. 62. Gorlanov, a peasant, was an SR from 1905 to 1918. He joined the Communist Party in 1920. TsDNIRO, f. 112 (Fedorovsk RK), op. 1, d. 1"b”, 1. 14.

35. See, for example, Mikoian's letter to Stalin of February 1925 in which he suggested the need for another purge of village-level Communists using the example of Berezhnoi, the Communist chairman of the Elisavetinsk village Soviet, who "terrorized the entire population, took bribes, beat people up, and even shot a few people who were said to be "trying to escape."' 
significant political, economic, and ideological concessions. ${ }^{36}$ The rhetoric of the period urged that farmers should be approached more respectfully than they had been previously. ${ }^{37}$ "The new task facing urban Communists," Mikoian explained to District Committee secretaries gathered at the July 1924 plenum of the North Caucasus Territorial Committee, "is to spend time with farmers (s krest'ianami). Whether they are good or bad, they are the only ones we have." ("Khoroshie oni ili plokhie, no oni edinstvennye, drugikh net." ${ }^{38}$ The development of new rural policies to complement this new "attitude" took nearly twelve months to complete. ${ }^{39}$ From 1925 through 1927, however, repressive actions on political grounds were rare and usually directly linked to attempts to organize village-wide tax boycotts. ${ }^{40}$

News of the Party's shift in policy and attitude was broadcast to local Party officials and rural inhabitants throughout the late fall and early winter of 19241925. Most farmers greeted the news as the peasants from Kasharsk county did rather coolly, "painstakingly comparing words with deeds." 41 The Cossacks of Novoshcherbinovka suspiciously inquired: "Could it be that you are allowing us to wear our old Cossack uniforms in order to make it easier to identify us during the next round of arrests?"42 Before speaking their minds, some, like the peasants in

36. The Party either genuinely desired to broaden its basis of popular support in the countryside or it made a bid, ultimately successful, to unmask its hidden adversaries. See Markus Wehner, "Die Lage vor Ort ist unbefriedigend'. Die Informationsberichte des sowjetischen Geheimdienstes zur Lage der russischen Bauern in den Jahren der Neuen Ökonomischen Politik (1921-1927)," Jahrbuch für Historische Kommunismusforschung (1994): 64-87 and Pride, ch. 5.

37. Isaac Deutscher, Stalin, a political biography, rev. ed. (Oxford, 1970): 302.

38. SKKKP, TsDNIRO, f. 7, op. 1, d. 9, 1. 67. Here, as in other places in this work, when it is clear that the speaker is not trying to exclude the Cossack farmer by using the word "krest'ianin," I will translate it "farmer." I prefer a cultural rather than economic definition of "farmers," whereby the agriculturalist's independent status as khoziain is the determining criterion, not the size of the farm, the degree of market involvement, or the technological sophistication of the machinery. For my argument in favor of "farmer" over "peasant" in general, see Pride, viii-xiv. I retain the terms "Cossack" and "peasant" as status indicators, because, even though the Revolution removed the legal basis for the distinction of status between Cossacks and peasants, women and men born prior to 1917 retained aspects of their previous "self perceptions," which, in the Don region at least, were intimately linked to their ascribed status backgrounds.

39. For overviews of the period, see I. Deutscher, op. cit.: 302-306; Moshe Lewin, Russian peasants and Soviet power, trans. by Irene Nove (London, 1968): 132-171; Mariia I. Buriakova, Politika partii po otnosheniiu $k$ krest'ianstvu v vosstanovitel'nyi period (19211925) (kand. diss., Moscow, 1952): 272-342; Iurii S. Kukushkin, Sel'skie Sovety i klassovaia bor'ba v derevne (1921-1932 gg.) (Moscow, 1968): 125-149.

40. On tax-protestors' fate, see Quarterly report (trekhmesiachnyi obzor - QR), Bataisk RK, 10 June 1926, TsDNIRO, f. 11 (Bataisk RK), op. 1a, d. 4a, 1. 13; QR, Sept. 1926, TsDNIRO, f. 101 (Semikarakorsk RK), op. 1, d. 17a, 1. 6. This assertion is based on a comparative reading of OGPU svodki from 1920-1924, 1925-1927, and 1928-1933, where the arrests unabashedly (almost proudly) noted in the first and third periods are strikingly missing, despite much more overt criticism in the second period.

41. QR, June 1925, TsDNIRO, f. 52 (Kasharsk RK), op. 1, d. 4,1.21.

42. Meeting of Village Cell Secretaries, Don district, 25-30 Jan. 1926, TsDNIRO, f. 5, op. 1, d. $70,1.138$. 
Kadnikovsk county (Vologda), secured a signed note from the District Committee secretary protecting them from the possibility of arrest. ${ }^{43}$

Nonetheless, peasants and Cossacks of all political stripes came to believe in the possibility of speaking their minds with impunity, in the main through a series of innovative and consistent transformations beginning with the Party's response to the famine of 1924-1925, continuing through the village Soviet elections of 1925, the freest local elections of the Soviet period, and concluding with a radically different style of newspaper reporting: frank and oriented toward exemplary, not unsuccessful, farmers. ${ }^{44}$ New attendance records were set at conferences and elections all over the Don in 1925.45 Transcripts of villagers' conference interventions between 1925 and 1927 are filled with direct and open expressions of villagers' chief grievances during the early years of Soviet power: taxes, insufficient schools, and workers' privilege, despite the presence of Soviet representatives. ${ }^{46}$ Even the steadfastly hostile section of the Cossack population believed a genuine change had occurred, a change which they read as an admission of weakness under the pressure of émigré Cossacks, and one which they hoped to exploit for very different ends than the Party intended ${ }^{47}$ Less defiant Cossacks even entered into dialogue with the Communists. Prior to 1925, some Cossacks may have attended a Party meeting, but they maintained an icy silence throughout what for them was clearly an ordeal. N. N. Patrikeev, chairman of the Don District Executive Committee, was particularly struck by the difference two years made even in an exceptionally conservative county like Konstantinovsk. "When I was here before," he recalled, "the town hall was packed with people. They all listened attentively, but didn't utter a single word for or against. They came, they listened, they left."48 In one Cossack market town, Shugolia, a member of the Don District Executive Committee announced upon his arrival that he had come "to sit on the embankment and to nibble sunflower seeds" - two favorite Cossack pastimes "and to discuss with peasants and Cossacks the questions that were on their minds." He found that within two days of his arrival, both peasants and Cossacks began to approach him, "posing all sorts of questions and speaking with a frankness not commonly shown to outsiders." 49

43. TsK IS, 19 May 1925, RTsKhIDNI, f. 17, op. 32, d. 25,1. 42.

44. Pride: chs 5 and 7.

45. Ibid.: 367-370.

46. In Pride, I devote two chapters ( 8 and 9) to villagers' economic and social objections from 1925-1927 based on a combination of sources drawn from OGPU svodki; letters written to Soviet journals, private letters intercepted by the OGPU or published in émigré journals; and conference interventions. On this point, the conference intervention is the most frank and multivoiced genre.

47. Pride, ch. 6 and RK QR, 1 Sept. 1926, TsDNIRO, f. 79 (Kamensk RK), op. 1, d. 17, 1. 2.

48. TsDNIRO, f. 101, op. 1, d. 7,1.22.

49. GARO, f. R-1485 (SKK ispolkom - SKKIK), op. 8, d. 89, 1. 22. 
From 1925-1927, it was not unusual for farmers to keep instructors up late into the night answering questions..$^{50}$ In the Morozovsk district, peasants from nearby villages attended a Party gathering for workers at one of the local state farms. At the request of the peasants, the speaker gave a short report on the state of international affairs. He was overwhelmed by the number of questions posed by both workers and peasants at the meeting, which lasted over seven hours. ${ }^{51}$ The questions themselves, sometimes written anonymously, provide invaluable inroads into the concerns and values of villagers. In the spring of 1925, political instructors complained of being bombarded by soldiers' questions like the following: "Why are white-collar workers eating meat [...] while farmers are existing on pumpkins and plain bread?"52 In December 1929, a farmer in Novyi Egorlyk asked: "Will there ever be a tax ceiling and, if so, when?"53

Second, before all villagers' articulations spoken with a Party or Soviet representative present can be disregarded as mere dissemblance, one must reconsider the assumption that all villagers, especially those attending conferences, considered representatives of the Soviet government as "dominators." In the Don region, peasant farmers felt very strongly that the pomeshchiki had been their primary thorns-in-the-flesh before 1917. Bolsheviks fought side-by-side with them from 1918-1920 in order to protect the revolution the peasants wrought on their own in the summer of 1917. Though peasant women did not fight in the revolutionary armies, many felt very strongly that they had made their own

50. A Non-Party Farmers' Conference in a Sal'sk county, for example, lasted until 5:00 a.m., despite the organizer's suggestion that they disperse for the night much earlier; TsDNIRO, f. 45 (Zapadno-Konnozavodchesk RK), op. 1, d. 1,11. 17-17ob.

51. Inspectors' reports, 1925, TsDNIRO, f. 72, op. 1, d. 16, 1. 46. A similar interest in international affairs was noted elsewhere. See, for example, reports from Vologda, TsK IS, 11 Nov. 1925, RTsKhIDNI, f. 17, op. 32, d. 19, 1. 225; Village Soviet Election Report (SSER), MKurgansk county, 26 Feb. 1927, TsDNIRO, f. 104, op. 1, d. 209, 1. 17; Semikarakorsk RKP, June 1926, TsDNIRO, f. 101, op. 1, d. 12, 1. 49; DOK IO, 1924, RTsKhIDNI, f. 17, op. 16, d. $938,1.7 \mathrm{ob}$. It does not, then, seem accurate to use M. Ia. Fenomenov's (Sovremennaia derevnia, 1925) conclusion that "the muzhik had no interest in anything outside the confines of his canton," as Richard Pipes does in The Russian Revolution, as proof of peasant apathy throughout the Russian portion of the Union. The quote is Pipes's paraphrase of Fenomenov; The Russian Revolution (New York, 1990): 109.

52. Mood report, 23 March 1925, TsDNIRO, f. 7, op. 1, d. 195, 1. 49. When reading reports (or letters like those edited by V. Izmozik, art. cit.) from 1924 and 1925, it is essential to keep in mind that the spring of 1925 was a drought-induced famine year for significant areas of the Soviet Union, including the following provinces: Kharkov, Omsk, Orlov, Odessa, Ul'ianovsk, Samarsk, Tambov, Penza, Orenburg, Stavropol, and Tula; TsK IS from the provinces, RTsKhIDNI, f. 17,op. 32, dd. 4, 9, 25. Although not as severe as the more infamous famines of $1891,1922,1933$, and 1947, death from starvation was not uncommon and in wide sections of the country, villagers, in places up to $50 \%$ and higher, ate surrogates, lay swollen from hunger, and experienced irreversible economic loss. Detailed sources are available - GARF has an entire fond on the course of the famine, grain exports, and relief efforts - including a thick file of OGPU reports from the various affected provinces (RGAE, f. 478, op. 1, d. 1804) and letters from home to soldier-relatives. Letters from Tambov, Voronezh and other Volga provinces written to relatives serving in the Red Army, who were stationed on the Don are available; see TsDNIRO, f. 7, op. 1, d. 200. For the Don region, see Pride: 221-222, 236-241.

53. Village Soviet election campaign, GARF, f. 1235 (VTsIK), op. 141, d. 114, 1. 61. 
contribution to the revolutionary cause. Some believed that in losing a son or a husband, they had already paid their dues. Others, such as the politically active women of Azov county, felt that because they "had kept the farms running" while their husbands were off fighting, they had as much of a right to participate in Soviet institutions as did the men. ${ }^{54}$

The Soviet government's policy of encouraging banks and cooperatives to prioritize their loans according to class standards in inverse order, when it worked, brought Sovvlast' intense gratitude from the recipients until collectivization. A number of former hired hands and poorer farmers credited the Soviet government for giving them a fresh start. In V. Nikolaevsk county (Sal'sk district), a poorer farmer, after receiving a loan enabling him to buy his own horse, announced: "Now I am even more convinced of the rightness of the cause for which I fought." 55 As the war scare of 1927 made clear, even the so-called peasant "kulaki" were ready to fight to the death for the Soviet government, because, in the words of one, "if the Bolsheviks leave [power], we're dead."56

The inogorodnie of the Don region - whose ancestors for the most part had arrived in the lower Don river basin area from central Russia between 1863 and 1883 "with nothing more than their bare hands"-were even clearer on who represented oppressive "power" in their lives: their neighbors, the Cossacks. ${ }^{57}$ As a participant at the June 1920 Don Provincial Party Conference pointed out, inogorodnii support in the Cossack market towns was conditional and intimately tied to Party treatment of the "Cossack question." "We will fight on the Don just as long as the Soviet government supports us in our struggle against the Cossacks," asserted one frank inogorodnii. ${ }^{58}$ Especially until the Party's change of tactics in late 1924 (and even after, though to a lesser degree), it was the inogorodnie in the

54. Conference of Department Heads of Workers among Women, 14-15 April 1925, TsDNIRO, f. 5, op. 1, d. 38, 1.59a.

55. V. Nikolaevsk RK IO, Oct. 1927, TsDNIRO, f. 79 (Kamensk RK), op. 1, d. 79, 1. 16 ob. Even a middling Cossack farmer from a Kuban market town voluntarily brought 10 puds of wheat as a present for the government in June 1928, because, he said, "I don't really need the money and the Soviet government is dear to me because it helped me to stand on my feet again." Report to the OGPU by the chairman of the TsKK, Starannikov, following his trip to the Kuban, 20 June 1928, GARF, f. 374, op. 27, d. 1490, 1. 27. See also Unpublished Farmers' letters (UFL) from Krest'ianskaia pravda (1 June 1928), RTsKhIDNI, f. 17, op. 85, d. 318, 1. 11. For similar stories, see OGPU IS, Taganrog district, 31 Aug. 1925, f. R-10, op. 1, d .307, 1. 18; UFL from Sovetskii pakhar' (July 1928), GARO, f. R-1485, op. 8, d. 139, 11. 3-4.

56. Gathering of RK secretaries, Don district, 21 July 1927, GARO, f. R-1798 (Don OIK), op. 3, d. $66,1.31$.

57. The quote is from Semen Nomikosov, who identified a second class of inogorodnie who arrived "with plenty of capital and a desire to purchase land and start their own business or trade operation"; by 1921, they had either fled over the nearest foreign border or been shot or deported by Bolsheviks. Statisticheskoe opisanie Oblasti voiska Donskogo (Novocherkassk, 1884): 331. See also V. V. Sementsova, Krest'ianskoe zemlevladenie na Donu v sviazi s deiatel'nost'iu Krest'ianskogo i Dvorianskogo zemel'nykh bankov (1885-1904 gg.) (kand. diss., Rostov, 1950): 6. On Cossack discrimination against inogorodnie before 1917, see Pride: 24-31.

58. Party Conference (PC), Don province, 3 June 1920, TsDNIRO, f. 4 (Don obkom), op. 1, d. $5,1.59$. 
Cossack areas who benefited most from Soviet rule. As of February 1926, in the Don district the percentage of land holdings available to the inogorodnie had increased by $67.5 \% .59$ Starannikov, chairman of a TsK Commission touring the Kuban in the summer of 1928, was told by local Party bosses he knew and trusted that, prior to the spring of 1928, the inogorodnie as a whole had proven themselves to be "strong supporters of the Soviet government, actively supporting it and fighting for it during [and, by implication, well after] the Civil War." As a result, he was told, "they are commonly called 'Bolsheviks' by many Cossacks."60

From 1925-1927, revolutionary Don villagers had no premonition that the Party's policy would be reversed. Instead, their conviction that the tone of the new era was meant to be permanent stemmed in large measure from their hope, encouraged by the Bolshevik Party itself, that the Party might reasonably serve as a powerful partner in bringing to fruition the dreams they had actively pursued and risked their lives to fulfill. During the village soviet elections of February 1927 in Taganrog, 15 peasants protested the attempt by the local cell to present its slate as a fait accompli, a return to pre-1925 tactics. They demonstrated their disapproval by getting up in the middle of the proceedings and making their ways to the exit. They were stopped by Kompaneets, a strong middling peasant, who argued: "There's no reason to leave. It's no longer 1918 nor 1920 when everything was arbitrary. Now the government is stable and one can register a complaint at the district level."61

Even if, for the sake of argument, one conceded that villagers felt an inevitable pressure to change the way they talked about Soviet power when aware of the presence of Soviet representatives throughout NEP, there would be no need to dismiss the conference genre out of hand, as villagers could still feel free to speak truthfully or write frankly about social tensions within villages, familial crises, and ethnic skirmishes, to name only a few topics. The presence of a Soviet representative actually emboldened the speaker to speak truth to (or at least about) the personification of oppressive power in his or her life when the conferenceattending villagers perceived the Party as a sympathetic advocate of their particular cause, i.e. for the inogorodnie an ally against Cossacks, for women an advocate against abuse and abandonment.

The ideal social milieu for free and open expression of the villagers' greatest concerns was a congregation of likes: farmers among farmers, peasant women among peasant women. Quasi-intelligentnye women, even wives of Party members, had a reputation for keeping "their distance from the peasant and Cossack women" at Party functions, which resulted in the latter two groups of women "feeling themselves somewhat out of place." ${ }^{2}$ Rural Communists were sometimes openly

59. As of 18 February 1926, Cossacks had lost $37 \%$ of their collective holdings. DKP, TsDNIRO, f. 5, op. 1, d. 52,1.48b.

60. GARF, f. 374 , op. 27 , d. 1490,1.1.

61. OGPU SSER, Feb. 1927, GARO, f. 2287, op. 3s, d. 20, 11.97-97ob.

62. Conference of Department Heads, Don district, 14-15 April 1925, TsDNIRO, f. 5, op. 1, d. 38, 11. 67-67a. 
laughed at as they haltingly gave their reports in the presence of the urban born at district meetings. ${ }^{63}$ At local meetings, better-schooled, exceedingly self-confident Cossacks openly sought to intimidate Party activists, who were less well educated and deeply insecure in the company of their Cossack neighbors. In Tersk, an older, male Cossack asked a young Cossack woman why she was writing "so crudely." To the young woman's defense - "I'm doing the best I can" - the man, shaking his head derisively, commented: "And to think you're a member of the Party."64 The tone of the power play was even more acerbic when the Communist activist was a despised inogorodnii. One non-Cossack activist was cut off in the middle of his life story (not a report about additional taxes or impending collectivization) by shouts from Veshensk Cossacks in the audience: "Enough chatter, already. Sit down!"'65 The conference interventions made by attendees at county-seat conferences for ordinary farmers and village women, district centers for County Committee secretaries are remarkable for fluency of expression, clarity of ideas, poignancy of the stories, and directness of the questions. ${ }^{66}$

For the traditionally least empowered members of the village community, it was particularly helpful if their congregating among social equals occurred far enough from home to discourage the attendance of those who might otherwise intimidate the meek or be in a position of personal "power" over the poorer farmer or wife. Traditionally marginal villagers were acutely aware that there were also off-stage repercussions for speaking what more powerful villagers did not wish to hear at local meetings. In Tarasovsk county, a poorer farmer was accosted on the street by a man the Donets District Committee secretary identified only as a "kulak." The "kulak," according to the secretary's account, "grabbed the poorer farmer by the scruff of the neck, insulted him with 'unprintable' words, and said: 'I will show you how to point out who has grain left at the meetings." ${ }^{67}$ Anti-Communist husbands brought pressure to bear on their wives by warning them, "If you go to those meetings, you will lose your good name."68 Even peasant men with a Civil War

63. Chernushko, a member of the Orlovsk cell, reprimanded the other delegates for laughing at comrade Vlasov. He pointed out that many of those who spoke so eloquently were also "lying through their teeth." Vlasov by contrast, according to Chernushko, "spoke from the heart." Congress of Village Cell Secretaries, Don district, 25-30 Jan. 1926, TsDNIRO, f.5, op. 1, d. 72,1.3.

64. Cossack Question Conference, June 1925, SKK, TsDNIRO, f. 7, op. 1, d. 215, 1.312. (Also available in published version: Kraevoe soveshchanie po rabote sredi kazachestva (Rostov, 1925).

65. OGPU IS, TsDNIRO, f. 7, op. 1, d. 801,1.54ob.

66. I make my comparisons on the basis of my reading of preniia from a wide range of conferences held in county seats, district centers, Rostov-on-Don, and Moscow between 1920 and 1933. On the history and purpose of Non-Party Farmers' Conferences, a particularly rich source from 1925 through 1927, see M. I. Buriakova, op. cit.: 262-271.

67. Progress reports from Donets OK to SKKK, 22 May 1928, TsDNIRO, f. 75 (Donets OK), op. 1, d. 93, 1. 114. "That type [of kulak]," the secretary assured the SKKK, "has been arrested by the GPU.” See also OGPU IS, TsDNIRO, f. 7, op. 1, d. 807,1. 199.

68. Meeting of village organizers, Don district, Jan. 1926, TsDNIRO, f. 5, op. 1, d. 82, 11. 102103; P. Goriunov, O kazach'em voprose. (Iz nabliudenii i opyta po Eiskomu raionu Donskogo okruga) (Rostov, 1925): 17. 
record were concerned by the possibility of legal recourse against male arbitrariness - a recourse that Bolshevism offered women, at least in principle. A young female Communist (komsomolka) sued (for train fare home) a komsomolets who had enticed her to leave the Kuban with him for the Don, only to dump her, penniless, shortly after arrival. She was defended by a female lawyer, the first one villagers had ever seen. The case drew the entire village into the courtroom to see "what kind of a lawyer a woman would make," and women to see if "peasant women really had rights." After the judge ruled in favor of the komsomolka, village men left the courtroom uttering threats: "If you women become lawyers, you won't live more than, say, another month, tops." 69 Similar kinds of threats were made to keep women from speaking at public meetings or voting counter to the wishes of the husbands on a regular basis. ${ }^{70}$

On the other hand, the conference location had to be close enough to home to justify time away from the fields for the farmers, and, for mothers, the possible necessity of leaving one's children unattended for a day. Twenty kilometers was a sufficient distance to keep husbands and even uncommitted females from the village of advocates who might, for personal reasons, "snitch" on the wife to the husband. One mother of four, in her words, "risked the trip" to the big city (Konstantinovka, population 10,000) in order to attend the District Conference of Peasant Women. She was driven by her desire to "find out everything we need to know," she explained, "so that I can pass on my knowledge to those at home."71

\section{Building materials}

Documents in "Shakhty Filial," in addition to Moscow libraries and archives, supply the building materials for a database of village histories. These materials include, but are not limited to, those written or inspired by villagers themselves. The historian can then return rural letter-writers or striking collective farm workers to their social, revolutionary, and historical contexts in order to more literally recreate their worlds.

Soviet reference books published in the 1920s, usually by the District Executive Committee, make it possible for us to know, at least approximately, mid-1920s figures for the following, even in most hamlets: the number of men and women, the percentage of Cossack residents vis-à-vis inogorodnie, the town's wealth in schools and mills, the number and type of plows per household, and the walking distance to

69. District Conference of Peasant Women Activists, Don district, 24-28 Feb. 1925, TsDNIRO, f. 5 , op. 1, d. $36,1.35$.

70. Village Commission Meeting, Don district, 12 March 1925, TsDNIRO, f. 5, op. 1, d. 84, 11. 37a-38a; TsDNIRO, f. 5, op. 1, d. 32,1.29.

71. Makhnova is not explicit about why she considered the trip so "risky." Perhaps it was her first foray out of the village and she had no idea what to expect; maybe she had left her children unattended and was worried for their safety. District Conference of Peasant Women, Don district, 24-28 Feb. 1925, TsDNIRO, f. 5, op. 1, d. 36, 1. 42. 
the nearest market town. ${ }^{72}$ A gleaning of the more deliberately analytical of the Soviet works from the 1920 s, problematic at best, usually uncovers useful raw data. ${ }^{73}$ Even Soviet dissertations written before 1953, to take an extreme case of simplistic ideological analysis, can add to our picture of a village or district, at least geographically or topographically. ${ }^{74} \mathrm{~A}$ wealth of geographical and social material which simultaneously provides a useful comparative tool is provided by prerevolutionary reference books and ethnographic studies. ${ }^{75}$

This database of village histories can also include major events and attitudes. For my study of Don villagers, I paid special attention to political allegiances and revolutionary proclivities of the $1905-1920$ period.$^{76}$ District Executive Committee instructors and Rabkrin inspectors, especially between 1925-1927, traveled from village to village, interviewing villagers and investigating local Communists. Their write-ups usually include a short history of the village before the revolution, presumably as retold by the villagers themselves or at least the local Communists, the peasants' status vis-à-vis their local pomeshchik, inogorodnii-Cossack

72. Spisok naselennykh mest Donskogo okruga Severo-Kavkazskogo kraia (Rostov, 1927); Spisok naselennykh mest Sal'skogo okruga Severo-Kavkazskogo kraia. Po predvaritel'nym itogam vsesoiuznoi perepisi naseleniia 17 dekabria 1926 goda (Sal'sk, 1927); Spisok naselennykh mest Severo-Kavkazskogo kraia (Rostov, 1925); Itogi vyborov $v$ sovety Donskogo okruga v 1925, 1926 i 1927 gg. (Rostov, 1927); A. I. Petrovskii, K kharakteristike rassloeniia Severo-Kavkazskoi derevni. (Materialy) (Rostov, 1925); Kazachestvo SeveroKavkazskogo kraia (Rostov, 1928).

73. Litso Donskoi derevni k 1925 g. (po materialam obsledovaniia DKK i DonRKI) (Rostov, 1925); I. Gol'dentul, Zemel'nye otnosheniia na Kubani. Kratkii ocherk (Rostov - Krasnodar, 1924); N. L. Iachevskii, ed., Kak zhivet i chem boleet derevnia (po materialam komissii po obsledovaniiu derevni na iugo-vostoke) (Rostov, 1924).

74. M.I. Ovchinnikova, Kollektivizatsiia sel'skogo khoziaistva v Sal'skom okruge (kand. diss., Rostov, 1953).

75. S. Nomikosov, Statisticheskoe opisanie; Ocherki geografii vsevelikogo voiska Donskogo (Novocherkassk, 1919); Statisticheskii obzor sovremennogo polozheniia kazach'ikh voisk (St. Petersburg, 1903); Petr Stoliarov, "Etnograficheskie svedeniia o zhiteliakh voiska Donskogo," in D. K. Zelenin, ed., Opisanie rukopisei uchenogo arkhiva imperatorskogo russkogo geograficheskogo obshchestva (Petrograd, 1914); Svedeniia o voiske Donskom: statisticheskie, istoricheskie, geograficheskie, etnograficheskie, sel'sko-khoziaistvennye $i$ prochie (Novocherkassk, 1878); K. V. Markov', "Krest'iane na Donu," in Sbornik oblastnogo voiska Donskogo statisticheskogo komiteta, 11 (Novocherkassk, 1900); V. G. Groman, "Novorossiiskie gubernii," in Agrarnoe dvizhenie v Rossii v 1905-1906 gg. (St. Petersburg, 1908) 2: 394-534; Kazach'i voiska: opyt voenno-statisticheskogo opisaniia (St. Petersburg, 1881); A. M. Grekov, "Khoziaistvo kolonistov v Taganrogskom okruge," in Sbornik oblastnogo voiska Donskogo statisticheskogo komiteta (Novocherkassk, 1901) 1: 98-106; A. M. Grekov, Ocherki ekonomicheskogo i khoziaistvennogo byta naseleniia Donskoi oblasti (Taganrog, 1905); V. V. Alekseev, Raspredelenie naseleniia po territorii Novorossii, ego etnograficheskii sostav, byt i kul'tura, vol. 14 of Rossiia: polnoe geograficheskoe opisanie nashego otechestva, V.P. Semenov-Tian'Shanskii, ed. (St. Petersburg, 1910); L. Ia. Apostolov, Geograficheskii ocherk Kubanskoi oblasti (Tiflis, 1897).

76. Many relevant documents have been published by Soviet historians: 1905-1907 gody na Donu. Sbornik dokumentov (Rostov, 1955); Ia. N. Raenko, ed., Khronika istoricheskikh sobytii na Donu, Kubani i v Chernomor'e, mart 1917 g. - mart 1918 g., 1 (Rostov, 1939); Iuzhnyi front (mai 1918 - mart 1919). Sbornik dokumentov (Rostov, 1962); Bor'ba za sovetskuiu vlast' na Kubani v 1917-1920 gg. Sbornik dokumentov i materialov (Krasnodar, 1957). 
skirmishes, and assertive acts in 1917: who fought with whom during the Civil War and from what date. Reports of unpopular local Party dictators and tales of repression from 1920 to 1924 are also prevalent, especially in Rabkrin reports. ${ }^{77}$ Patterns of interaction that developed out of confrontations between the Party and the peasantry over key issues - grain, taxes, elections, and the right to organize in a Farmers' Union (Soiuz khleborobov) - can also be added to most villages' profiles. County-generated OGPU reports are laced with detailed tales of complaints, social squabbles, acts of local violence, street-corner gossip, and drunken toasts, which make them rich repositories of villagers' attitudes toward and expectations of Farmers' Unions, comparative evaluations of tax burdens from year to year, and feelings of Cossack partisans in Sal'sk in 1927 as well as monarchists, who look forward to the day when "princes" will once again rule Russia.

Almost all of the sources mentioned above are vulnerable to the criticism that they have been drafted, or at best transcribed, by men and occasionally women who were not only outsiders, but who almost always hailed from a non-farmer class. Most of these report writers, of course, had better writing skills than their villageraised counterparts, but the former also shared common prejudices about the "backwardness" of village life and the superiority of everything urban. "Both village and city Communists alike," Mikoian admitted in the summer of 1924, "are scornful of the peasantry." 78 In fact, urban Party members often went to great lengths to avoid village assignments. ${ }^{79}$ As one city-bred Communist informed Mikoian, "My soul belongs to Tula and Ivanovsk - I work well with the proletariat. I couldn't possibly work with peasants." 80 Those urban Party workers who temporarily ended up in a village or market town smaller and less culturally "sophisticated" than that to which they were accustomed, often made no attempt to hide their dissatisfaction from the people they were supposed to be recruiting in their efforts to build socialism. One such young man several kilometers from his native city announced: "Fellow Young Communists, I don't want to work here at all. Here there is only dirt and darkness. Life in Eisk is better." ${ }^{1}$

77. See especially GARF, f. 374; GARO ff. R-97 (Don OIK), R-1185 (SKK RKI), and R-1485; TFGARO, f. R-10, ShFGARO, ff. R-278 and f. R-754 (Millerovsk County KK RKI).

78. SKKKP, 31 July 1924, TsDNIRO, f. 7, op. 1, d. 9, 1. 66.

79. Memo from Donets OK to Don obkom, 24 June 1924, TsDNIRO, f. 4, op. 1, d. 192, 1. 34; Taganrog OKP, 1925, TsDNIRO, f. 104, op. 1, d. 157, 1. 51; Memo on the sending of workers to the countryside, Shakhtinsko-Donets district, TsDNIRO, f. 118 (Shakhtinsko-Donets OK), op. 1, d. $69,1.73$.

80. SKKKP, 31 July 1924, TsDNIRO, f. 7, op. 1, d. 9, 1. 66.

81. Meeting of Village Cell Secretaries, Don district, 25-30 Jan. 1926, TsDNIRO, f. 5, op. 1, d. $70,1.166$. 
Of course, there are no bias-free sources, and here the bias is often overt, which in a way aids in the unpacking process..$^{82}$ Labels, such as "kulak"or "backward" can be peeled off, in a sense, to reveal a more interesting, colorful reality underneath. One "saving grace" is that a person unable to see the intelligence, the code of honor, or the unique talents of a group of people as a result of prejudicial blinders on one subject is nonetheless still capable of observation and reasonably accurate reporting on more neutral questions, from land-holding patterns and geographical variations to local rivalries and voting outcomes. Perceptive outsiders who were not intimidated by the Cossacks' superiority complex, possibly because of their self-evident urban "superiority," were sometimes able to listen to Cossack or inogorodnii rhetoric about the other and draw more neutral, less invested conclusions.

A second saving grace is that, particularly between 1925 and 1927, there were a number of significant exceptions to the scornful-worker rule. In fact the phenomenon was significant enough to warrant a label in later years by disgusted higher Party officials, who complained of "peasant sympathizers." Scattered local Communist leaders sometimes took the lead in private conversations among the local farmers, arguing in favor of the need for a Farmers' Union because "Communists are meeting capitalists, not farmers, half-way." 83 Others sometimes critiqued the Communist Party's record in the countryside to its face, like Revnov, a local Party authority from the Sal'sk district at a 1926 Party Conference: "We often talk about socialism, but in point of fact, at least with regard to the countryside, we are quite far from it. With one hand we take back what we just gave with the other. Often we take so much, that it turns out that the farmer pays even more than he was given in the first place." 84 In 1927, a Don District Committee instructor was shocked by his discovery that "ordinary farmers" were being disfranchised and personally led a movement to protest the "outrage" to the higher authorities of Taganrog. 85

Between 1925 and 1927, the Party line approached farmers with respect, motivating even careerists to think twice before writing exclusively disparaging reports, a third redeeming factor. These inspectors, usually affiliated with the District Control Commission or the District Executive Committee, spent on average several weeks in one village, observing and asking questions of the farmers themselves. They were, in Mikoian's opinion, “among the Party's brightest and best people capable of demonstrating to farmers that there are city folk who

82. Even Agnes Smedley, who was a daughter of impoverished parents - her father, onequarter Cherokee; her mother, an Ozarkian farmer's daughter - and who would spend her entire life fighting for one revolutionary cause or another, from Indian independence to Chinese revolution and better treatment for orphaned children in the Soviet Union, described the young Mexican men at her first teaching job in stereotypically prejudicial terms for 1907; Janice R. MacKinnon, Stephen R. MacKinnon, Agnes Smedley: The life and times of an American radical (Berkeley - Los Angeles, 1988): 13.

83. Leningrad, May, 1926, RTsKhIDNI, f. 17, op. 32, d. 86,1. 19.

84. PC, Sal'sk district, 20 Dec. 1926, TsDNIRO, f. 97, op. 1, d. 58, 1. 15.

85. GARO, f. R-2287, op. 3s, d. 20,1.93. 
understand the needs of farmers." 86 Their primary mission was to ride herd on the abusive local Party members; those who were clearly discredited in the eyes of the local community were removed from their positions or at least transferred to another county or district.

Weekend forays by bus or electric train can provide an opportunity to evaluate at least some urban Communists' prejudicial comments. ${ }^{87}$ The market town of Eisk is only a three-hour electric train ride from Rostov. Half a day spent walking the streets of Eisk and three hours walking around a small village twenty kilometers away quickly convinced me that the young man who saw only "dirt and darkness" was communicating far more about himself than about the city, the village, or the Cossacks who lived there. Eisk itself remains, by Taganrog standards, "a big village" to this day: cows are led to pasture every morning down central streets, horse-drawn carts outnumber cars, and chickens cackle in every yard. While there is, to be sure, no shortage in either place of dirt and dust blown across the plains by the winds lofting from the sea of Azov, there is a great deal of color and beauty in almost every yard as well, displayed especially by the determined effort to raise flowers or lilacs (the historical sign of a Cossack homestead) and by the decorations in bright blues, reds, and yellows hand-painted on each house. Moreover, unlike in Kasharsk, a peasant market town much further north or even in parts of Rostov, every sidewalk is well swept, a result mainly of bent older women wielding short hand-made brooms. My firsthand observations of beauty, color, and order complemented the descriptions of the nineteenth-century ethnographer, Mikhail Kharuzin, and thus suggest that these efforts are traditional points of pride, not Soviet inventions. ${ }^{88}$

\section{Returning letter-writers to their villages}

In January of 1928, S. I. Prodan, by his own description a better-off (zazhitochnyi) farmer even before 1917, penned a letter to the editors of his favorite newspaper, Sovetskii pakhar'. During the previous year, he had been labeled a "kulak" and deprived of his right to vote in the Soviet elections for hiring a replacement worker in order to free his oldest child, a ten-year-old boy, from field work long enough to attend school. The "kulak" label, he argued, was both unjust from a revolutionary point of view and personally offensive (not merely inconvenient or worrisome) to him because of his revolutionary credentials. He was not a "kulak," but rather an exemplary Soviet citizen because, as he put it, "when peasant blood flowed from

86. Cossack Question Conference, June 1925, SKK, TsDNIRO, f. 7, op. 1, d. 215, 1. 12.

87. Part of my research strategy involved touring Rostov province by foot, boat, bus, motorcycle, taxi, and electric train in order to see the markedly different landscapes my subjects grew up looking at and to live with various acquaintances and friends from diverse walks of life. These experiences not only gave me another angle to view my non-peasant sources from, but also gave me a feeling for the rhythm of small towns and villages.

88. Mikhail Kharuzin, Svedeniia o kazatskikh obshchinakh na Donu (Moscow, 1885). 
Moscow to the Black Sea," he was there, risking his life for the right side (the only side, from his perspective). Moreover, Prodan continued, he had spent the postwar years rebuilding his farm and paying taxes, thereby helping put the Soviet Republic back on its feet. Ultimately, he concluded, the decision would cause published Lenin's final testament to go unfulfilled, because he had to sacrifice his son's right to study in order to save his honor. ${ }^{89}$

From one angle, Prodan's letter can be viewed as the perfect example of why peasant letters to Soviet newspapers are best seen as a distorting mirror even of the letter-writer's mental world, an attempt by the powerless to appeal to the powerful in the latter's own terms through its approved medium. Very possibly the letterwriter was desperate after being labeled a kulak - what good had ever come to kulaki at any time during the Soviet era? Maybe he had even gone so far as to fabricate both the Civil War history and the story about his son's desire for an education. In lieu of a conclusion, I would like to suggest another interpretation based on an application of the principles that I have contended are necessary (and possible) in light of the (primarily) county-generated sources.

The editors of Sovetskii pakhar', a Rostov-based agricultural newspaper, enjoyed a personalized, almost affectionate, relationship with the subscribers. In part, the professed warm feelings must have stemmed from the joy farmers derived from reading the deliberately accessible articles written on a subject so dear to their hearts: how to improve one's farming skills. ${ }^{90}$ The chief editor, Makhar'ev, spoke of being constantly assaulted by readers and village correspondents, in a mood of expectant waiting: "Say, how's it coming with our Farmers' Union? We've written letters and published opinion pieces in our local papers." By the same token, Makhar'ev knew his writers and, within limits, defended them. He assured the Don District Committee that the letters agitating for a Farmers' Union - visualized as a counterpart to workers' trade unions - "come from people we know, poor and middling peasants, not 'kulaki'."'91

In January of 1928, the Sovetskii pakhar'staff retained an unusual amount of trust from its readers. Letter-writers in 1927 and 1928, writing to protest the loss of voting rights or the violence accompanying the grain-procurement campaigns in the spring of 1928, were often direct on this point. Confirmation of the betrayal of this trust is provided by the veritable flood of frank, detailed letters written to Sovetskii pakhar' itself protesting the violations of the litsom-contract, which ranged from physical violence and arrests to the abolishment of free speech at the meetings. ${ }^{92}$

89. UFL to Sovetskii pakhar', TsDNIRO, f. 7, op. 1, d. 769,1. 17.

90. See, for example, UFL to Sovetskii pakhar' (1-13 July 1928), GARO, f. R-1485, op. 8, d. 139, 11. 3-4. He was far from alone in treasuring his subscription on agricultural grounds: see also, DKK inspection report, Novo-Minsk, 1925, GARO, f. R-1798, op. 1, d. 1023, 11. 149-150; SSER, 2 March 1926, TsDNIRO, f. 72, op. 1, d. 11,1.20ob.

91. TsDNIRO, f. 5, op. 1, d. 145, 11. 76-77.

92. According to Makhar'ev, "an exceptionally high number of farmers wrote to protest the way the grain procurements campaign was being carried out in their areas"; 13 March 1928, TsDNIRO, f. 7, op. 1, d. 769, 1. 103. Letter-writers often (hopefully) suggested: “surely it can't 
This trust was not naively given by the peasants, but painstakingly won between 1924 and 1927 by the editors, who were acting under the guidelines of the new era of Party-farmer relations. During these years submissions like the one penned by T. Fedotov, entitled "How then are we supposed to live?," were not publicly rejected so that readers would take a lesson about "inappropriate topics," as in 1921.93 Instead, a deliberate and conscious effort was made by newspaper editors to win the trust of its readership. ${ }^{94}$ District Committees guarded against making unrealistic promises. When an article was printed in Sovetskii iug proclaiming the advent of electrification in rural areas surrounding Millerovo, the Donets District Committee worried that "incorrect information" would have "a detrimental effect on the circulation of newspapers and on readers' trust" and forced the editors to print a correction: "There was absolutely no possibility that electricity would be installed in the nearest villages, not to mention within a 100-kilometer radius" from the district center. ${ }^{95}$ Letters from farmers complaining of inefficient or inattentive rural Party secretaries or Soviet bosses were printed in full, along with a commentary chastising the offending authorities. ${ }^{96}$

By July 1928 this trust had been broken, as an anonymous letter-writer from the North Caucasus Territory told Comrade Makhar'ev directly. Trust betrayed, however, implies trust once earned, a fact the letter-writer also articulates. "You wrote a lot that was good. I personally believed you, but now, as a result of the grain-procurement campaign, I don't anymore." 97 When the newspaper articles continued to misrepresent the situation in the countryside, many farmers, including the anonymous one quoted above, honored their threats and canceled their subscriptions. ${ }^{98}$

Nonetheless, even if Prodan believed himself to be writing to a sympathetic and influential representative of Soviet power, there is no definitive way to determine whether Prodan was a talented con artist or a true believer. Certain details in his letter, however, are verifiable: Peschansk, his hamlet, was a small school-less settlement of

be like this everywhere in the whole country." GARO, f. R-1485, op. 8, d. 139, ll. 46, 58. Makhar'ev also noted, in January 1928, the passionate displeasure of the letter-writers protesting the revocation of voting privileges. "Even though almost an entire year has passed, the kulak is still unable to calm down"; TsDNIRO, f. 7, op. 1, d. 769, 1. 15. In fact, one of several strategies used by farmers to regain the franchise was to appeal to what in 1927 was still considered to be the reasonable, influential ear of Soviet power - farmers' newspapers - in both their local and central manifestations.

93. Editor's comments in Verkhne-Donskaia pravda(15 June 1921).

94. See the complaints of the chief editor of Sovetskii pakhar' in 1928 that their efforts of the past years were effectively being undone by the new restrictions of 1928, UFL to Sovetskii pakhar', 1928, TsDNIRO, f. 7, op. 1, d. 769,1.103.

95. Donets OKB, 1926, TsDNIRO, f. 75, op. 1, d. 71,1. 122.

96. See, for example: Belokon', Sal'skii pakhar' (22 April 1926); Komsomolets Erik, "Po selam i stanitsam. Emu nekogda," ibid. (9 Sept. 1925); "Nam pishut,” ibid. (8 July 1925).

97. See, for example, UFL to Sovetskii pakhar' (1-13 July 1928), GARO, f. R-1485, op. 8, d. 139, 11. 3-4; UFL to Sovetskii pakhar' (1928), TsDNIRO, f. 7, op. 1, d. 769, 11. 13-15; UFL to Krest'ianskaia pravda(June 1928), RTsKhIDNI, f. 17, op. 85, d. 318,1.11.

98. UFL to Sovetskii pakhar', (received) July 1928, GARO, f. R-1485, op. 8, d. 139, 11. 3-4. 
63 men and women, located five kilometers from the county center, Tarasovka, and twenty kilometers from Millerovo, the Donets district center. ${ }^{99}$ For Prodan's son to have attended school would have required a ten-kilometer walk, daily.

Other rural Party members articulated the popular connection between the Revolution they fought with the Bolsheviks to defend and their expectations of more schools for their children. In the words of Tishchenko, a Party member since 1920, at the Matveevo-Kurgansk County Party Conference in 1926: "We have an enormous number of government-supplied liquor stores. This is not what we fought for." 100 The right to attend a Party school for "developmental" training was a badge of honor. Early dismissals were said to have caused emotional distress and disillusionment with the Party. One such candidate entered a Party school barely able to read. After two months, he was expelled on the grounds that he was "a hopeless cause." "They say that power is ours now. On practically every page of the newspaper, we are exhorted to study," he responded. "Then when a person actually does go away to school, they chase him away."101

Moreover, with the exception of Old Believers, rural parents strongly approved of and materially supported increased educational opportunities for their children. A. D. Mitin, secretary of the Nikolaevsk County Committee (Taganrog district), drew the Party's attention to the frequency and urgency of the demands for more schools “at every Soviet congress, at every citizens' gathering, and at every session of the village soviet." 102 Their independent actions lend authority to their demands spoken in the face of Soviet and Party representatives. In Kushchevsk county, a movement among the religiously fervent to build a new church was unsuccessful because the vast majority of the population preferred to spend their available energy, money and time building a new school.103 This contrasts sharply with attempts to raise funds for schools in Old Believers' communities, which failed because the Cossacks were committed to repairing their church building. Often during the 1920s farmers themselves were the driving force behind the schools that were repaired, maintained, and supplied with fuel for the winter session. ${ }^{104}$

99. Spisok naselennykh mest Severo-Kavkazskogo kraia, op. cit.: 325-326.

100. TsDNIRO, f. 104, op. 1, d. 195, 1. 55.

101. Meeting of village organizers, Don district, 8-13 Jan. 1926, TsDNIRO, f. 5, op. 1, d. 84, 1. $125 \mathrm{a}$.

102. TsDNIRO, f. 104, op. 1, d. 195, 1.94 and f. 104, op. 1, d. 193, 1. 7. Similar demands were made elsewhere and reported by a wide variety of source types: DK inspector's report, Kushchevsk county, 1927, TsDNIRO, f. 5, op. 1, d. 160, 1. 164; Eisk RKP, 3 March 1928, TsDNIKK, f. 1297 (Eisk RK), op. 1, d. 60, 1. 13ob; Questions by peasant farmers asked in Ermakovsk at a Non-Party Farmers' County Conference: TsDNIRO, f. 111, op. 1, d. 17, 1. 34ob; OGPU IS, Taganrog district, 7 Dec. 1924, TFGARO, f. R-10, op. 1, d. 307, 1. 503; Meeting of RK Chairmen and Village Cell Secretaries, Sal'sk district, 1924, TSDNIRO, f. 97 , op. 1, d. 33, 1. 1ob.

103. QR, Sept. 1926, TsDNIKK, f. 163 (Kushchevsk RK), op. 1, d. 35a, 1. 27.

104. QR, Oblivsk RK, Oct. 1925, TsDNIRO, f. 118, op. 1, d. 75, 1. 176ob; QR M. Berezovsk RK, Oct. 1925, ibid., 1. 73; Secret letter by the chairman of the Morozovsk RIK, Sept. 1925, ShFGARO, f. R-278, op. 2, d. 42,1.12ob. 
Communities without schools, after encountering resistance from officials at the local level - no funds, no buildings, no teachers - came up with their own funds, built the necessary buildings, and sent scouting commissions in search of teachers. ${ }^{105}$

These written and spoken sources, multitudinous in number, were confirmed for me by Mariia Savel'na Dudareva, the daughter of a northern Don Cossack, and Petr Mikhailovich Samoilov, the son of the USSR's second best viticulturalist from the Crimea during the 1950s, who had only four years of schooling to his credit. Both stressed that their fathers were "among the [in Samoilov's case, the very best] best-educated in the village." But it was the look of unparalleled pride on both faces during the recounting - comparable in Dudareva's case only to her pride in her father's role in helping to build the brick church in the village square in 1903 - that influences the way I write about the complicated, intriguing topic of farmers and education. Their gaze belies what we have been led to expect by the historiographical refrain of backward peasants who have no use for book learning. 106

Furthermore, through a careful reading of a multiplicity of documents, it can be determined that there were a substantial number of real "Prodans" out there, i.e. men with similar stories. At least two other men made very similar written arguments, including V. I. Spivak, a farmer from the Stavropol district, who wrote, also in 1928: "What kind of an enemy is the [prosperous] individual farmer who worked side by side with hired hands, poorer and middling farmers to defend and build up Soviet power?"107 In the Don region, economic differences among villagers had played virtually no role in determining enlistment preferences in 1917, in large measure because of the significant and discriminatory Cossack presence. In the village of B. Orlovka, for example, where approximately $90 \%$ of the men had fought on the Red side during the Civil War, the owners of steampowered threshers had joined the Red Army just as readily as their poorer neighbors. ${ }^{108}$ Testimonials to Red Army participation are preserved in the archives, not only in the Control Commission's village histories, which are most vulnerable to manipulation - but can also be garnered from Red and White reconnaissance reports from 1917 through $1920 .{ }^{109}$ District Committee instructors had little reason

105. Village organizers' meeting, Don district, Jan. 1926, TsDNIRO, f. 5, op. 1, d. 80, 11. 77a78; "Pobol'she vnimanie derevne," Krasnyi Don, 17 Dec. 1920; IO, Fedorovsk RKB, Dec. 1925, TsDNIRO, f. 104, op. 1,d. 174,1.63.

106. Private conversations with M. Dudareva, May 1991, and with P. Samoilov, April 1995. To the ethnographer, these corporal clues are often as significant as the words themselves. See, for example, the splendid ethnographic oral history of Alt-Hildesheim, Andrew Stuart Bergerson, A history of neighborliness in Alt-Hildesheim, 1900-1950: Custom, transformation, memory (Ph.D. diss., University of Chicago, 1998), esp. ch. 6 on greetings.

107. UFL to Sovetskii pakhar' (12 Jan. 1928), TsDNIRO, f. 7, op. 1, d. 769, 1. 10. See also Sal'sk OKP, 8 Feb. 1927, TsDNIRO, f. 97, op. 1, d. 71,1. 11.

108. Litso donskoi derevni, 26, 29, 41, 82; GARO, f. R-1485, op. 8, d. 89, 1. 4.

109. See for example, Hoover Institution Archive, Vrangel' collection box 041, file “150,” 11. $187 \mathrm{ob}-188$. 
to encourage deception in 1920 in a moment of inadequate food supplies, when Red loyalty meant a right to a share of an inadequate pot. The reports mention just as often villages where only a few able-bodied young men enlisted or especially Cossack villages where most joined the White army. ${ }^{110}$ The OGPU transcripts of overheard conversations during the 1920s and 1930s often touch upon the complaints of Civil War veterans, both Red and White. Red soldiers from Sal'sk, in the words of a Cossack soldier from Atamansk (overheard in conversation with two other Cossacks), fought for the Bolshevik cause "from the very first days of the Revolution." His conversation merited recording by the OGPU reporter because of his complaint "that former soldiers were being replaced by women sent from the center."111

Finally, we can be least certain about whether Prodan was genuinely offended by his newly acquired "kulak" status. What we can piece together is that for Prodan, the loss of his voting right was a far more pressing issue than the use of violence accompanying the self-taxation and grain-procurements campaigns of 1928. His letter mentions neither event, even though in the Tarasovsk county and Prodan's township, Turoverovo-Rossoshinsk, in particular, both the grain-procurement and self-taxation drives of 1928 had been accompanied by an exceptional use of force, according to independent reports from the secretary of the Donets District Committee and a local village reporter. ${ }^{112}$ Though we must be careful not to extend our knowledge of future events to farmers who had only seen pomeshchiki and "real" kulaki (by their village standards) disappropriated and deported, by late 1927 it had to be clear to most that to be labeled a "kulak" according to the Soviet definition of the word - an enemy of the Party - brought numerous economic disadvantages. Still, as Prodan conveyed, he was not the only better-off pro-Soviet farmer "deeply offended" for being equated with kulaki in Soviet newspapers, where ordinary villagers were being urged to treat them as trouble-making elements "to be kept away from the elections." 113 In the gentler days of the mid1920s, better-off farmers had taken offense, in the words of the Khopersk District Committee secretary, at "the Party's propensity to call any prosperous khoziain a 'kulak."' 114 In Kamensk county, for example, one peasant, a very strong supporter of the Soviet government, had been so offended at being called a "kulak" that he "sold all of his belongings except for one horse and said: 'Now I'm a poorer farmer. Are you satisfied?"” 115

110. On desertions from a White source, see 21 March 1919, ibid., 1. 179.

111. OGPU IS, Sal'sk district, 18 April 1927, TsDNIRO, f. 97, op. 1, d. 76, 1. 29.

112. Progress report on the grain procurement campaign to Andreev (SKKK) from the Secretary of the Donets OK, 27 Jan. 1928, TsDNIRO, f. 75, op. 1, d. 93, 1. 175; letter to Makhar'ev, editor of Sovetskii pakhar', from the village correspondent Okun', 1928, TsDNIRO,f. 7, op. 1, d. 769, 1. 43ob. Numerous other 1928 letters did.

113. UFL, TsDNIRO, f. 7, op. 1, d. 769,1. 17.

114. TsK IS, 11 Nov. 1925, RTsKhIDNI, f. 17, op. 32, d. 19, 1. 235.

115. Cossack Question Conference, June 1925, SKK, TsDNIRO, f. 7, op. 1, d. 215, 1. 66. Iuragov added: "Such cases are numerous." 
Among an even more unlikely group, the Cossacks, however, corroboration from a range of sources exists to substantiate the following letter written by young Cossacks, also lishentsy, to Sovetskii pakhar' in January 1928: "We consider it a mistake to deprive the younger generation of its rights in our free country. We don't want to be left behind by our comrades. We too want to study military and political matters, so that in the future, we can be prepared to defend our free country." 116 Just one year prior, Goriunov, a non-Party Cossack activist working in the Eisk area, asserted: "It's now hard to distinguish between Cossack and non-Cossack youths. Cossack young men are just as eager as non-Cossack youths to participate in the Soviet army." 117 Goriunov was not one to overstate Cossacks' turn to the Party. On the one hand, he described the homes of defiant Cossacks where portraits of generals and former tsars still lined the walls. At the same time, he pointed out the more modest Cossack huts, where only one wall was covered with postcards and photographs of Cossacks in full military dress. On the opposite wall icons and portraits of tsars had been replaced by portraits of Trotskii, also in military attire, and of Lenin attending the First All-Russian Cossack Congress. ${ }^{118}$ The most telling confirmation of this comes from Cossack letters to émigré relatives. In one, a father complains of his son's "dream of a career in Soviet Russia," noting that he had chosen a military one. ${ }^{119}$ Most interesting, however, is the letter published in Vol'noe kazachestvo , an émigré journal, in 1927: "Yes, you are right a thousand times over when you say that I have no hope of changing your political views. At the same time, however, you will never change my mind no matter what you write. [...] Our small, but mighty young Communist Guard is always on the alert."120

I worked in the Shakhty Filial archive a total of three weeks in the spring of 1994. During that time Rimma Ivanovna and I argued over "relevant" dela and discussed our respective countries, politics, and philosophies over strong tea or brandy. ${ }^{121}$ The day I left, after the honorary lunch of boiled potatoes drenched in sunflower oil, vegetables cut "peasant-style," and watermelon, Rimma Ivanovna confided that her father had been incorrectly dekulakized for corresponding with Polish relatives in 1937. The proudest day of her life, she confided, was when she was told "you're the daughter of a kulak, but you're worthy of being called a

116. UFL to Sovetskii pakhar' (12 Jan. 1928), TsDNIRO, f. 7, op. 1, d. 769, 11. 18-19.

117. Don OKP, 1927, TsDNIRO, f. 5, op. 1, d. 99b, 1. 207. Fathers, too, continued to provide their sons with horses they could trust and be proud of. Don OKB, 1927, TsDNIRO, f. 5, op. 1, d. 130,1.10a.

118. P. Goriunov, op. cit.: 16-17.

119. Excerpt from an intercepted letter from abroad, OGPU Cossack Report, 1 May 1927, TsDNIRO,f. 7, op. 1, d. 595,1.597.

120. "Pis'mo komsomol'tsa," Vol'noe kazachestvo, 1 (10 Dec. 1927): 28.

121. I deliberately refrained from formal methods of oral history for this project. Spontaneity and a sense that the confidences being offered to a virtual stranger (or after two years, a close friend) are of importance to the speaker, not just the sociologist with her list of pre-determined questions to pursue, are the chief advantages of a "method" without microphones and preplanned questionnaires. 
Communist." Rimma Ivanovna's reminiscences of youthful commitments and passions, especially in a day when orthodox Communist values are open to critique and ridicule, serve as an interpretative aid, pushing me beyond the limits of my late twentieth-century skepticism and rationalism.

Memphis, Fall 1998.

University of Memphis

History department

Campus box 526120

Memphis TN38152-6120

e-mail: deepenner@email.msn.com 